\title{
PSYCHOMETRIC PROPERTIES OFTHE SLOVAK VERSION OF EXPERIENCES IN CLOSE RELATIONSHIPS-REVISITED (ECR-R) ON GENERALADULT SAMPLE
}

\author{
Gabriela ROZVADSKÝ GUGOVÁ ${ }^{1}$, Anton HERETIK ${ }^{1}$, Michal HAJDÚK ${ }^{2}$ \\ ${ }^{1}$ Dubnica Institute of Technology, Department of Pedagogy and Psychology Sciences \\ Sládkovičova 533/20, 01841 Dubnica nad Váhom, Slovak Republic \\ E-mail: gugova@dti.sk \\ ${ }^{2}$ Faculty of Philosophy, Department of Psychology, Comenius University \\ Gondova 2, 81499 Bratislava, Slovak Republic
}

\begin{abstract}
Experiences in Close Relationship-Revisited (ECR-R) is the most frequently used measure of self-reported adult attachment. Numerous studies have shown its general utility and similarity across language translations and cultures; some studies showed important differences in attachment style structure and also the need to reword/adapt some items. We explored the psychometric properties of the Slovak translation of ECR-R on a general adult sample (Study 1, $\mathrm{n}=921)$. In Study $2(\mathrm{n}=100)$ participants also filled out the Slovak version of NEO-FFI for further information on its relation to the major personality structure theory for concurrent and sEMBU for convergent validity. The results showed good psychometric properties of the Slovak translation of ECR-R. Factor analysis sorted items to scales exactly as authors of ECR-R presupposed. We found mild to moderate correlation between Anxiety and Neuroticism and Avoidance and Neuroticism; and mild correlation to some sEMBU scales. We also discuss what would help to improve knowledge and utility of the Slovak version of ECR-R.
\end{abstract}

Key words: attachment styles, adult attachment, experiences in close relationships, ECR-R, psychometric properties

\section{INTRODUCTION}

The Theory of Attachment went from a minor and specific theory of early childcaregiver bond creation to a grand and general developmental theory of the impact of early childhood experiences with a close relationship on adult relationships with a romantic partner, close friends as well as relationships in the workplace and other social and even neuroscientific and health related contexts (Atkinson, Goldberg, 2004; Cassidy, Shaver, 2008; Obegi, Berant, 2009; Ravitz et al., 2010; Wake, 2010). Originally, the theory was postulated by Bowlby (1969) in the 50's as a psychoanalytic and ethologic theory of the impact of child behavior in a strange, new and insecure situation, as the result of the child's relationship quality with the caregiver (mother). Eventually the topic was broadened to include general research of early experiences and their impact on adults forming and experiencing different relationships in different situations, not only in insecure and threatening ones (also not all current theorists agree with such broadening of the original theory, see Mikulincer, Shaver, 2007 for

DOI: $10.21909 / \mathrm{sp} .2014 .01 .649$ 
discussion). Bowlby reasoned that in a new, potentially threatening and basically uncertain and insecure situation the child would naturally look for the support and security in the attachment figure - typically the mother, but in many cases the child who has experienced detachment and was left unsupported forms an ambivalent and even avoidant relationship with the original caregiver. Mary Ainsworth and colleagues (see Cassidy, Shaver, 2008) later created a widely used experiment paradigm to study the different behavior of a child seeking his/ her mother's support. This experiment was standardized into the famous Ainsworth's Strange Test and based on observation of interactions it proposed three different attachment "styles" - "secure", "avoidant" and "anxious". Other measures of attachment were developed later and they were based basically on "objective" observer-interview methods and self-reports. Research interest was broadened to include attachment behavior and experiencing in adulthood (Cassidy, Shaver, 2008; Mercer, 2006; Mikulincer, Shaver, Ravitz, 2010).

In the 80's there was a significant shift from the original theory when Hazan and Shaver (1987) applied the Ainsworth "styles" in the context of adult romantic relationship experiences. The basic idea was that early childhood experiences with the caregiver have significant impact on adults experiencing romantic relationships with a partner and that similar styles or types as proposed by Ainsworth could be found in adulthood. It is important to note, that this interest was rooted in social and personality psychology not in developmental research. This has created many controversies around the topic of attachment (due to different focus in theorizing, different focus on behavior vs. expe- rience and assessment methods). As for basically any theory, the development of a measure instrument was crucial. To study adult behavior and experiencing romantic relationship many inventories (mostly self-reporting) were gradually created. In accordance with the general development of methodology in psychology, original categorical agreement/disagreement measures of different attachment styles were factor-analyzed and turned into continuous scales (see Fraley et al., 2000; Ravitz et al., 2010). In the beginning of 90's, Bartholomew and colleagues promoted the utility of a fourth adult attachment style, which was called "dismissingavoidant". The four types better fitted into the supposed two-dimension model of attachment, one dimension describing the level of anxiety and the other the level of avoidance in experiencing attachment in close relationships. One of the most popular measures of adult attachment, mostly used to assess attachment experiences in romantic relationships, is the Experiences in Close Relationships (ECR) questionnaire by Brennan, Clark, and Shaver (1998).

The Experiences in Close RelationshipsRevised (ECR-R), is a "revised" version of the ECR. The revised version contains items from the original ECR and also from the Adult Attachment Scales, the Relationship Styles Questionnaire, and the J. Simpson's attachment scales (Fraley et al., 2000). Fraley et al. (2000) used the Item Response Theory (IRT) methods for items selection. Both instruments have become popular in research of adult attachment. Many national standardizations and samples in different countries found general support for the validity of the ECR and ECR-R and their items, but there were several interesting differences and sometimes rewording or even different fac- 
tor structure were proposed (Alonso-Arbiol, 2007; Cameron et al., 2012; Lečbych, Pospísilíková, 2012; Olsson et al., 2010; Parker et al., 2011). As the translated version of the ECR-R is already utilized in numerous research projects in Slovakia and Czech Republic, we found it necessary to look for the psychometric properties of the Slovak version of the ECR-R.

Looking at attachment experiences and behavior from a wider perspective, there are several other important variables related to the relationship processes, experiences and behavior than the self-rated attachment behavior. Besides social processes, the relationship between personality features and attachment comes first to mind. Numerous studies looked into this relationship, many of them focusing on mainstream personality structure concepts like the Five-Factor Theory of Personality (typically measured by NEO inventories (Costa, McCrae, 1995), or Biopsychological theory of personality developed by Cloninger et al. (Cloninger, Svrakic, 1997) and typically measured by Temperament and Character Inventory (TCI). They routinely found a medium to strong relationship between the Anxious dimension and Neuroticism (or Harm-avoidance in TCI), and a mild to medium relationship between Secure dimension and Extroversion, Agreeableness and negative to Neuroticism. Attachment avoidance has been moderately negatively correlated with Extraversion and Agreeableness. The other relationships were not so clear and differed from study to study (see Chotai et al., 2005; Cooper, 2002; Noftle, Shaver, 2006; Picardi et al., 2005; Surcinelli et al., 2010). Of course, the underlying theory of the nature of the relationship between personality and attachment cannot be explained by correlation studies and deserves continual research effort, yet looking into the wider context of psychometric properties of the Slovak ECR-R we decided to relate it to the NEO-FFI as most widely used measure of the Five-Factor Theory of Personality. The goal of using the NEO-FFI is to provide the estimate of how much of the variance in the Anxiety and Avoidance score in the ECR-R can be related to personality features, prominently Neuroticism.

Another complex relationship and a subject of controversies is the relationship between adult attachment and child-parent(s) relationship in childhood (for discussions see also Cassidy, Shaver, 2008; Fraley, Shaver, 2000; Mikulincer, Shaver, 2007). For the purpose of our study, we decided to look at the relationship between participants childhood memories of parental rearing behavior, using the shortened version of the EMBU (sEMBU). The EMBU is a Swedish acronym for Egna Minnen Beträffande Uppfostran (My memories of upbringing, Arrindell et al., 1999). It is an 81-item questionnaire with 15 subscales and two additional questions concerning the severity and consistency of parental educational behavior. The shortened version consists of 23 questions grouped into 3 subscales - Rejection, Emotional warmth and Overprotection. The questions are answered separately for the father and the mother using the 4-point Likert scale.

Arrindell et al. (1999) administered the sEMBU to students in 11 countries in Europe, Asia, Australia and South America as part of an international study evaluating individual personality and fears. The general patterns of correlations between factors in the long version of EMBU were as follows: a statisticaly significant and considerably negative correlation between Rejection and Emotional warmth, statistically significant 
and positive association between Rejection and Overprotection and statistically non significant and negligible association between Emotional warmth and Overprotection. Coefficients of internal consistency (Cronbach's a) for all scales were satisfactory $(\geq 0.72)$.

Different versions of the EMBU have been standardized in more than 25 countries and translations (Livianos-Aldana, RojoMoreno, 2003).

The goal of the presented research project was to analyze psychometric properties of the Slovak translation of the ECR-R (Bieščad, Hašto, 2010) and to provide concurrent and convergent validity of the instrument. For better clarity we decided to split our results into two studies presented bellow. Study 1 focuses on general psychometric properties of ECR-R $(\mathrm{N}=921)$ and in Study 2 we analyzed ECR-R and its relationship to NEO-FFI and $\operatorname{sEMBU}(\mathrm{N}=100)$.

\section{STUDY 1}

\section{PSYCHOMETRIC PROPERTIES OF THE SLOVAK VERSION OFTHE ECR-R}

\section{METHODS}

We administered the ECR-R to 921 participants, which were recruited during their external pre-gradual study in the Dubnica Institute of Technology (DTI) in 2010-2012. Participants were selected on availability basis and willingness to participate without any rewards. All of them finished high school with final A-exam. They lived all throughout Slovakia, as DTI has many small local consultation centers in all regions of Slovakia. Gender and age properties of the sample can be seen in Table 1.

The psychometric properties of the Slovak version of the ECR-R were analyzed applying the following procedures: general descripton, item-total correlation, Cronbach $\alpha$, exploratory factor analysis, attachment styles analysis and correlation analysis of the relationship of the ECR-R and sEMBU and the NEO-FFI personality inventory (Ruisel, Halama, 2007). We divided our research results into two studies. Study 1 focuses on general psychometric properties of the ECR-R $(\mathrm{n}=921)$ and in Study 2 we analyzed the ECR-R and its relationship to NEOFFI and $\mathrm{sEMBU}(\mathrm{n}=100)$.

The sample for Study 1 consisted of 493 women and 427 men. One person did not complete gender information. Mean age of participants was $\mathrm{M}=30.20 ; \mathrm{SD}=8.64$ (from 18 to 55$)$.

\section{RESULTS OF \\ PSYCHOMETRIC PROPERTIES OF THE SLOVAK VERSION OFTHE ECR-R}

Descriptive statistics (Raw scores) for the ECR-R subscales are displayed in Table 2. The mean score for the Anxiety subscale

Table 1. Gender and age description of the whole research sample

\begin{tabular}{|l|c|c|c|}
\hline & Men & Women & Total \\
\hline $\mathrm{N}(\%)$ & $471(46.2 \%)$ & $549(53.8 \%)$ & 1020 \\
\hline Age range & $18-55$ & $19-52$ & $18-55$ \\
\hline Age mean & 31.0 & 29.4 & 30.18 \\
\hline Age SD & 8.33 & 8.88 & 8.66 \\
\hline
\end{tabular}


Table 2. Descriptive statistics (Raw scores) of the two ECR-R scales in the whole sample $(\mathrm{n}=921$, Study 1$)$

\begin{tabular}{|l|c|c|c|c|c|c|c|c|}
\hline ECR-R & Mean & SD & Median & Ptil05 & Ptil 25 & Ptil 75 & Ptil 95 & Ptil 99 \\
\hline Avoidance & 46.52 & 15.61 & 44 & 24 & 35 & 57 & 75 & 84 \\
\hline Anxiety & 57.04 & 17.48 & 57 & 30 & 44 & 69 & 87 & 100 \\
\hline
\end{tabular}

Note: Ptil $=$ Percentil

was $\mathrm{M}=57.20 ; \mathrm{SD}=17.63$; and for the Avoidance scale it was $\mathrm{M}=45.74$; $\mathrm{SD}=$ 14.85. The authors of the ECR-R worked with the overall item mean scores. The mean item score of the ECR-R in our study for Anxiety was: $\mathrm{M}=3.18, \mathrm{SD}=.97$; and Avoidance: $\mathrm{M}=2.54, \mathrm{SD}=.82$. We used raw scores in our analyses and tables, because we find it more accessible for the reader and it is also possible to report statistics in terms of percentiles.

\section{Basic Statistical Description of ECR-R Scales, Gender, Age and Marital Differences}

There were statistically significant differences between men and women in the Anxiety $(\mathrm{t}(919)=2.721, \mathrm{p}<0.05, \mathrm{~d}=0.181)$ and Avoidance $(\mathrm{t}(919)=2.427, \mathrm{p}<0.05, \mathrm{~d}=0.206)$ subscales scores. Men experience higher avoidance in close relationships, by contrast, women experience more anxiety in their close relationships (Table 3 ).

Correlations between the ECR-R and age were significant but low $(\mathrm{r}<.100)$. Our sample consisted mostly of young adults (mean and median around 30 years).

Next, we analyzed the relationship between the ECR-R scale scores and marital status (Table 4). There were no statistically significant differences in the Avoidance subscale based on marital status $(\mathrm{F}(2,603)=.061, \mathrm{p}=$ 941). Statistically significant differences were found for the Anxiety scale $(\mathrm{F}(2,603)=3.713$, $\mathrm{p}=.025)$. Descriptive statistics for groups based on marital status are in Table 4. Posthoc analysis (Tukey) revealed that single participants scored significantly higher than married ones $(\mathrm{p}=.038)$ on the Anxiety scale. Differences between the single and the divorced group were not significant $(\mathrm{p}=.235)$. Non significant results could be caused by the small sample size of the divorced group.

\section{Psychometric Properties of the ECR-R Subscales}

Internal consistency for the subscales were $\alpha=.820$ for Anxiety and $\alpha=.831$ for Avoidance. The Slovak version of the ECR-R seems to be quite reliable. Means, SDs and Item-

Table 3. Descriptive statistics (Raw scores) of the two ECR-R scales in men and women (n=921, Study 1)

\begin{tabular}{|l|c|c|c|c|c|c|c|c|}
\hline ECR-R & Mean & SD & Median & Ptil05 & Ptil 25 & Ptil 75 & Ptil 95 & Ptil 99 \\
\hline Avoidance Women & 44.63 & 15.11 & 42 & 23 & 34 & 55 & 73 & 83 \\
\hline Avoidance Men & 47.00 & 14.49 & 45 & 26 & 36 & 55 & 75 & 82 \\
\hline Anxiety Women & 58.69 & 17.74 & 57 & 32 & 45 & 71 & 91 & 100 \\
\hline Anxiety Men & 55.56 & 16.90 & 55 & 30 & 43 & 67 & 85 & 96 \\
\hline
\end{tabular}

Note: Ptil $=$ Percentil 
total correlations for the Avoidance and Anxiety subscale are presented in Table 5.

Items 9, 23, 24, 36 showed some mean differences between males and females (Cohen's $d$ were: .27; .30; .36; -.32). Men scored higher on item "It helps to turn to my romantic partner in times of need". By contrast women had higher scores on items: "I worry a lot about relationships"; "It makes me mad that I don't get the affection and support I need from my partner"; "I worry that I won't measure up to other people".

Table 4. Differences (Raw scores) in Anxiety and Avoidance scales (ECR-R) in marital status groups (Study1)

\begin{tabular}{|l|l|l|c|}
\hline Marital status & Mean & SD & N \\
\hline \multicolumn{4}{|c|}{ Anxiety scale } \\
\hline Single & 58.87 & 18.46 & 354 \\
\hline Married & 54.92 & 17.31 & 212 \\
\hline Divorced & 53.82 & 17.32 & 39 \\
\hline Total & 57.16 & 18.08 & 605 \\
\hline \multicolumn{4}{|c|}{ Avoidance scale } \\
\hline Single & 45.12 & 14.54 & 354 \\
\hline Married & 45.52 & 15.85 & 212 \\
\hline Divorced & 45.77 & 15.75 & 39 \\
\hline Total & 45.30 & 15.07 & 605 \\
\hline
\end{tabular}

Table 5. Item reliability of ECR-R scales (Study 1 and Study 2)

\begin{tabular}{|c|c|c|c|c|c|c|c|}
\hline $\begin{array}{c}\text { Anxiety } \\
\text { scale }\end{array}$ & Mean & SD & $\begin{array}{c}\text { Item-total } \\
\text { correlation }\end{array}$ & $\begin{array}{c}\text { Avoidance } \\
\text { scale }\end{array}$ & Mean & SD & $\begin{array}{c}\text { Item-total } \\
\text { correlation }\end{array}$ \\
\hline 1 & 3.57 & 1.94 & .444 & 2 & 2.85 & 1.76 & .361 \\
\hline 3 & 2.98 & 1.75 & .300 & 6 & 3.79 & 1.96 & .265 \\
\hline 4 & 2.66 & 1.82 & .613 & 10 & 2.75 & 2.00 & .224 \\
\hline 5 & 3.17 & 1.89 & .593 & 12 & 3.46 & 1.98 & .333 \\
\hline 7 & 4.96 & 2.08 & .354 & 14 & 3.18 & 1.80 & .448 \\
\hline 8 & 2.01 & 1.55 & .340 & 16 & 2.14 & 1.62 & .523 \\
\hline 9 & 3.18 & 1.99 & .478 & 18 & 2.56 & 1.69 & .555 \\
\hline 11 & 3.42 & 1.97 & .347 & 20 & 2.61 & 1.76 & .354 \\
\hline 13 & 2.94 & 1.86 & .430 & 21 & 1.75 & 1.29 & .493 \\
\hline 15 & 3.41 & 2.03 & .279 & 25 & 2.44 & 1.60 & .530 \\
\hline 17 & 3.78 & 2.18 & .344 & 26 & 1.99 & 1.46 & .509 \\
\hline 19 & 2.71 & 1.85 & .475 & 28 & 1.86 & 1.48 & .367 \\
\hline 22 & 2.43 & 1.73 & .428 & 29 & 1.84 & 1.43 & .393 \\
\hline 23 & 4.3 & 2.24 & .338 & 32 & 2.93 & 1.81 & .469 \\
\hline 24 & 3.37 & 1.94 & .388 & 33 & 2.99 & 1.70 & .356 \\
\hline 27 & 3.11 & 1.96 & .467 & 34 & 2.69 & 1.71 & .416 \\
\hline 30 & 2.4 & 1.64 & .404 & 35 & 2.53 & 1.66 & .491 \\
\hline 31 & 2.65 & 1.72 & .631 & 36 & 2.17 & 1.65 & .381 \\
\hline
\end{tabular}




\section{Principal Component Analysis}

A principal component analysis with Direct Oblimin rotation was performed on the ECR-R (see Table 6). Eight factors had greater eigenvalue than $1(49.75 \%$ of variance). We consider the 2-factor solution to be the most parsimonious. An extracted 2 -factor solution explained $28.28 \%$ of variance. The Keiser-Mayer-Olkin measure was satisfactory $(\mathrm{KMO}=.888)$. Bartlett's test of Sphericity was highly significant $(\mathrm{p}<.001)$. The Data were suitable for the Principal component analysis. The eigenvalue for the first factor (Avoidance) was 6.753 and for the second factor (Anxiety) it was 3.431. The items of the ECR-R were grouped identically in line with the theory behind the ECR-R. Items number 8, 13, 19, 22, 30 contributed to both extracted factors. But all of these items had higher factor to factor loading, which represented the subscale proposed by Fraley. Only item n.10 (see Table 9) had a smaller factor loading than .300 . Pattern matrix and factor loadings are presented in Table 6. We found it favorable that the exploratory 2-factor solution sorted the relevant items of the ECR-R into the factor structure originally proposed by Fraley et al. (2000), although the explained variance is rather low.

Table 6. Pattern matrix and factor loadings of the ECR-R $(n=921$, Study 1$)$

\begin{tabular}{|c|c|c|c|c|c|}
\hline Item & Avoidance & Anxiety & Item & Avoidance & Anxiety \\
\hline 1 & & .596 & 19 & & .453 \\
\hline 2 & .375 & & 20 & .474 & \\
\hline 3 & & .385 & 21 & .644 & \\
\hline 4 & & .711 & 22 & .338 & .373 \\
\hline 5 & & .699 & 23 & & .439 \\
\hline 6 & .323 & & 24 & & .452 \\
\hline 7 & & .549 & 25 & .685 & \\
\hline 8 & .328 & & 26 & .600 & \\
\hline 9 & & .536 & 27 & & .561 \\
\hline 10 & .271 & & 28 & .424 & \\
\hline 11 & & .363 & 29 & .440 & \\
\hline 12 & .360 & & 30 & & .400 \\
\hline 13 & & .436 & 31 & & .698 \\
\hline 14 & .518 & & 32 & .607 & \\
\hline 15 & & .345 & 33 & .365 & \\
\hline 16 & .629 & & 34 & .440 & \\
\hline 17 & & .458 & 35 & .555 & \\
\hline 18 & .683 & & 36 & .482 & \\
\hline
\end{tabular}

Avoidance scale items: 2, 6, 10, 12, 14, 16, 18, 20, 21, 25, 26, 28, 29, 32, $33,34,35,36$

Anxiety scale items: $1,3,4,5,7,8,9,11,13,15^{*}, 17^{*}, 19,22,23,24,27$, 30,31

*reverse scored 


\section{Attachment Styles}

We conducted the K-means cluster analysis on the factor scores from the ECR-R Principal Component analysis (see Figure 1). We used the factor scores from the Varimax rotation because the 2-dimensional model of attachment styles is based on the idea that factors are uncorrelated but we found moderate correlation between the ECR-R subscales. The aim of the cluster analysis was to classify cases into four attachment types based on their factor scores. The extracted clusters represent the following attachment styles: Fearful $=$ higher anxiety and higher avoidance (17.8\%); Secure= lower anxiety and lower avoidance (43.3\%); Dismissive $=$ lower anxiety and higher avoidance $(16.7 \%)$; Preoccupied $=$ higher anxiety and lower avoidance $(22.2 \%)$. The percentage of our sample belonging to one of the four groups is illustrated in Figure 1. We found statistically significant gender differences in attachment styles (Figure 2).

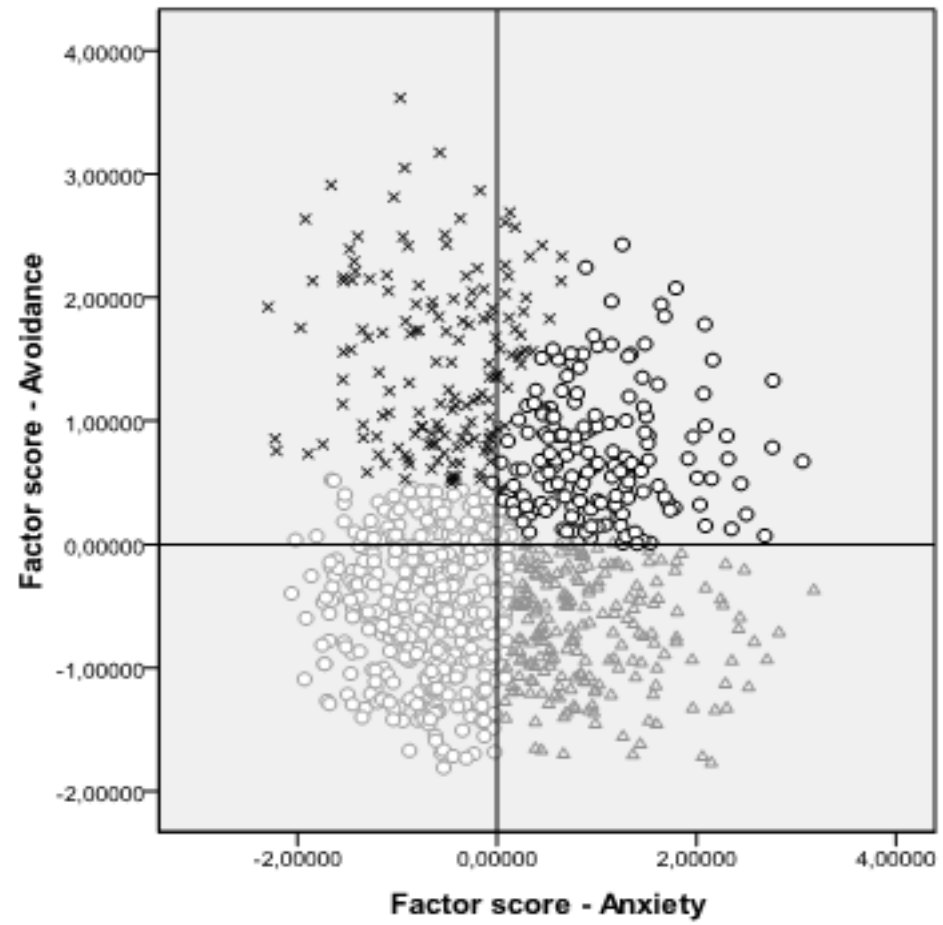

\section{Attachment styles \\ Secure \\ $\triangle$ Preoccupied $\times$ Dismissive OFearful}

Figure 1. Attachment styles $(\mathrm{N}=921$, Study 1) 


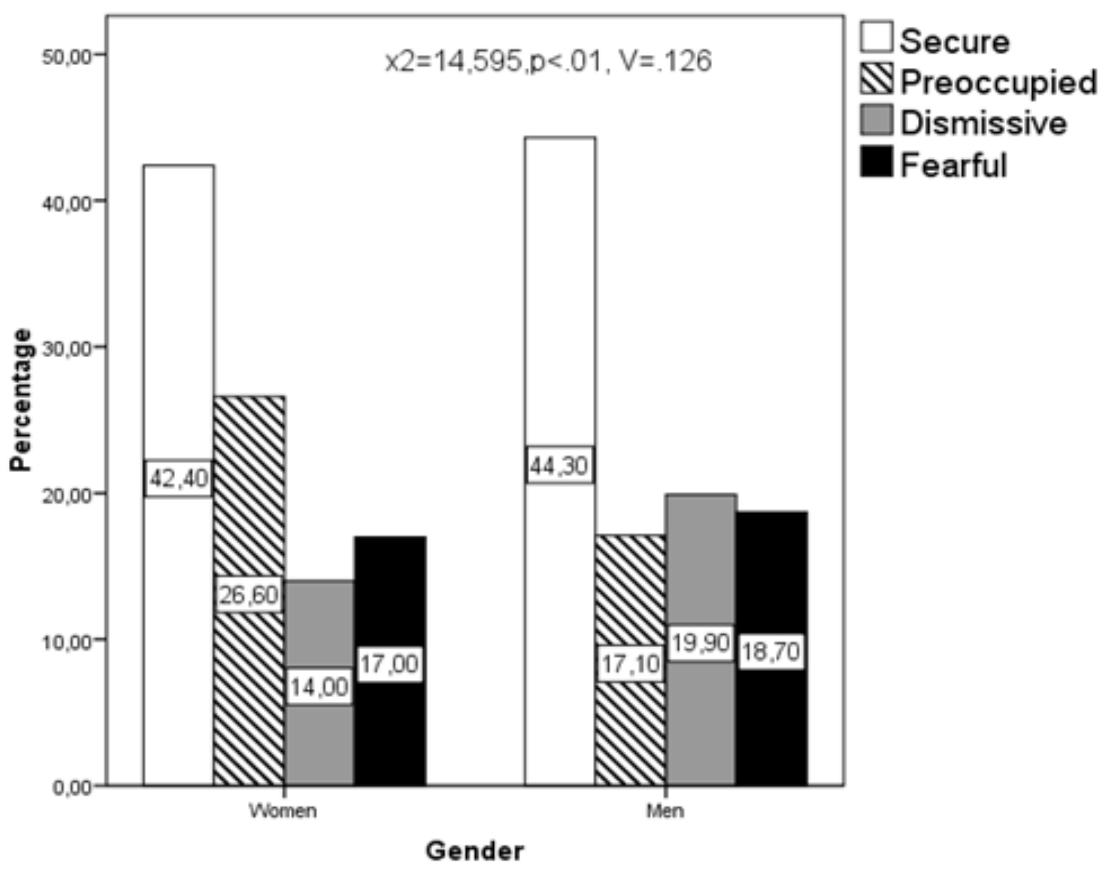

Figure 2. Gender differences in attachment styles $(n=921$, Study 1$)$

\section{STUDY 2 \\ VALIDATION OF THE ECR-R INTHE CONTEXT OF PERSONALITYFEATURES AND REMEMBERED PARENTINGSTYLES}

\section{METHODS}

To examine the ECR-R from a wider perspective we decided to ask additional 100 particiants from the same institution as in Study 1 to also fill in the Slovak translations of the NEO-FFI (Ruisel, Halama, 2007) for concurrent validity; and the sEMBU (Arrindell et al., 1999, Slovak translation Poliaková et al., 2007) for convergent valid- ity. Research sample for Study 2 consisted of 56 women and 44 men. Mean age of participants was $\mathrm{M}=30.05 ; \mathrm{SD}=8.81$ (from 19 to 51).

\section{RESULTS}

The mean scores and standard deviations for the Anxiety and Avoidance subscales were $\mathrm{M}_{\text {anx }}=54.62, \mathrm{SD}=19.79 ; \mathrm{M}_{\text {avoid }}=46.66$, $\mathrm{SD}=19.86$ (Mean item score: $\mathrm{M}_{\text {anx }}=3.24$, $\left.\mathrm{SD}=1.14 ; \mathrm{M}_{\text {avoid }}=2.59, \mathrm{SD}=1.10\right)$. Differences between the means of the ECR-R from the first study and from this sample were not significant. Gender differences were not statistically significant either. Correlation between the ECR-R subscales was $\mathrm{r}=.446$; $\mathrm{p}<$ .001 , which is higher than in Study 1 . 


\section{Psychometric Properties of the ECR-R Subscales}

Internal consistency was $\alpha=.883$ for the Anxiety subscale and $\alpha=.904$ for the Avoidance subscale, which was satisfactory and comparable to Study 1 . The mean Item-total correlation for the Avoidance subscale was .565 (from .386 to.761) and for the Anxiety subscale it was .516 (from .287 to .723). Correlations between the ECR-R and age were not significant.

\section{Concurrent Validity}

Concurrent validity was evaluated by correlating the ECR-R subscale with NEO-FFI.
Table 7 displays the relationship between measures. Mean scores and standard deviations for NEO-FFI facets are also included in Table 7.

We used the Spearman rank coefficient because of the violation of normal distribution of scores in several subscales. Based on the Kolmogorov-Smirnov test, only both ECR-R scales, Neuroticism, Openness, and Overprotection - mother scores were normally distributed. Statistically significant differences between men and women were found only in the Neuroticism subscale $(\mathrm{U}=$ $-660.5 ; \mathrm{p}<.001)$. We found a moderate correlation between the Anxiety scale and Neuroticism $(\rho=.438)$ and a mild correlation of Avoidance and Neuroticism $(\rho=.271)$ (Table 8).

Table 7. Correlations between ECR-R and NEO-FFI $(\mathrm{N}=100$, Study 2)

\begin{tabular}{|l|c|c|c|c|c|c|}
\hline \multicolumn{2}{|c|}{} & Neuroticism & Extraversion & Openness & Agreeableness & Conscientiousness \\
\hline Anxiety & $\boldsymbol{\rho}$ & $.438^{* *}$ & -.079 & -.132 & -.127 & -.066 \\
\cline { 2 - 7 } Scale & $\mathrm{p}$ & .000 & .435 & .191 & .208 & .511 \\
\hline Avoidance & $\boldsymbol{\rho}$ & $.271^{* *}$ & -.128 & .067 & $-.251^{*}$ & $-.231^{*}$ \\
\cline { 2 - 7 } Scale & $\mathrm{p}$ & .006 & .203 & .508 & .012 & .021 \\
\hline M & & 21.72 & 30.71 & 26.88 & 29.54 & 36.30 \\
\cline { 2 - 7 } SD & 8.86 & 6.12 & 5.52 & 6.26 & 6.29 \\
\hline
\end{tabular}

** Correlation is significant at the 0.01 level (2-tailed)

* Correlation is significant at the 0.05 level (2-tailed)

Table 8. Correlations between ECR-R scales and sEMBU indexes $(\mathrm{N}=100$, Study 2$)$

\begin{tabular}{|c|c|c|c|c|c|c|c|}
\hline & & $\begin{array}{c}\text { Overprotection } \\
\text { Father }\end{array}$ & $\begin{array}{c}\text { Overprotection } \\
\text { Mother }\end{array}$ & $\begin{array}{l}\text { Rejection } \\
\text { Father }\end{array}$ & $\begin{array}{c}\text { Rejection } \\
\text { Mother }\end{array}$ & $\begin{array}{c}\text { Emotional } \\
\text { Warmth } \\
\text { Father }\end{array}$ & $\begin{array}{c}\text { Emotional } \\
\text { Warmth } \\
\text { Mother }\end{array}$ \\
\hline Anxiety & $\rho$ & $.373^{* *}$ & .019 & .141 & .047 & -.001 & -.019 \\
\hline Scale & $p$ & .000 & .850 & .163 & .643 & .989 & .852 \\
\hline Avoidance & $\rho$ & $.197^{*}$ & -.050 & $.205^{*}$ & .138 & -.182 & $-.236^{*}$ \\
\hline Scale & $\mathrm{p}$ & .050 & .622 & .040 & .170 & .070 & .018 \\
\hline $\mathrm{M}$ & & 20.20 & 22.85 & 10.70 & 10.77 & 16.06 & 18.17 \\
\hline SD & & 4.38 & 4.48 & 3.91 & 3.57 & 4.55 & 3.77 \\
\hline
\end{tabular}

** Correlation is significant at the 0.01 level (2-tailed)

* Correlation is significant at the 0.05 level (2-tailed) 


\section{Convergent Validity}

The theory of adult attachment in general supposes that relationships in adulthood, at least partially, mirror an early infant-caregiver relationship pattern. Remembered parental behavior, measured by the sEMBU, was uti- lized to explore this link. Overprotection by the father was mildly correlated to Anxiety $(\rho=.373, p<.001)$ and Avoidance $(\rho=.197, p$ $<.05)$. Avoidance scale was mildly correlated to Rejection by Father $(\rho=.205, \mathrm{p}<.05)$ and Emotional warmth by Mother $(\rho=-.237, \mathrm{p}<$ $.05)$. The complete correlation matrix is in Table 8.

Table 9. ECR-R items numbering order as used in both studies (Study 1 and Study 2)

\begin{tabular}{|l|}
\hline 1. I'm afraid that I will lose my partner's love. \\
\hline 2. I don't feel comfortable opening up to romantic partners. \\
\hline 3. My desire to be very close sometimes scares people away. \\
\hline 4. I often worry that my partner doesn't really love me. \\
\hline 5. I worry that romantic partners won't care about me as much as I care about them. \\
\hline 6. I find it easy to depend on romantic partners. \\
\hline 7. I often wish that my partner's feelings for me were as strong as my feelings for him or her. \\
\hline 8. My partner only seems to notice me when I'm angry. \\
\hline 9. I worry a lot about my relationships. \\
\hline 10. It's not difficult for me to get close to my partner. \\
\hline 11. I do not often worry about being abandoned. \\
\hline 12. I prefer not to show a partner how I feel deep down. \\
\hline 13. When I show my feelings for romantic partners, I'm afraid they will not feel the same \\
about me. \\
\hline 14. My partner really understands me and my needs. \\
\hline 15. I rarely worry about my partner leaving me. \\
\hline 16. I talk things over with my partner. \\
\hline 17. Sometimes romantic partners change their feelings about me for no apparent reason. \\
\hline 18. I usually discuss my problems and concerns with my partner. \\
\hline 19. I find that my partner(s) don't want to get as close as I would like. \\
\hline 20. I feel comfortable depending on romantic partners. \\
\hline 21. I am very comfortable being close to romantic partners. \\
\hline 22. My romantic partner makes me doubt myself. \\
\hline
\end{tabular}

Table 9 continues 
Table 9 (continued)

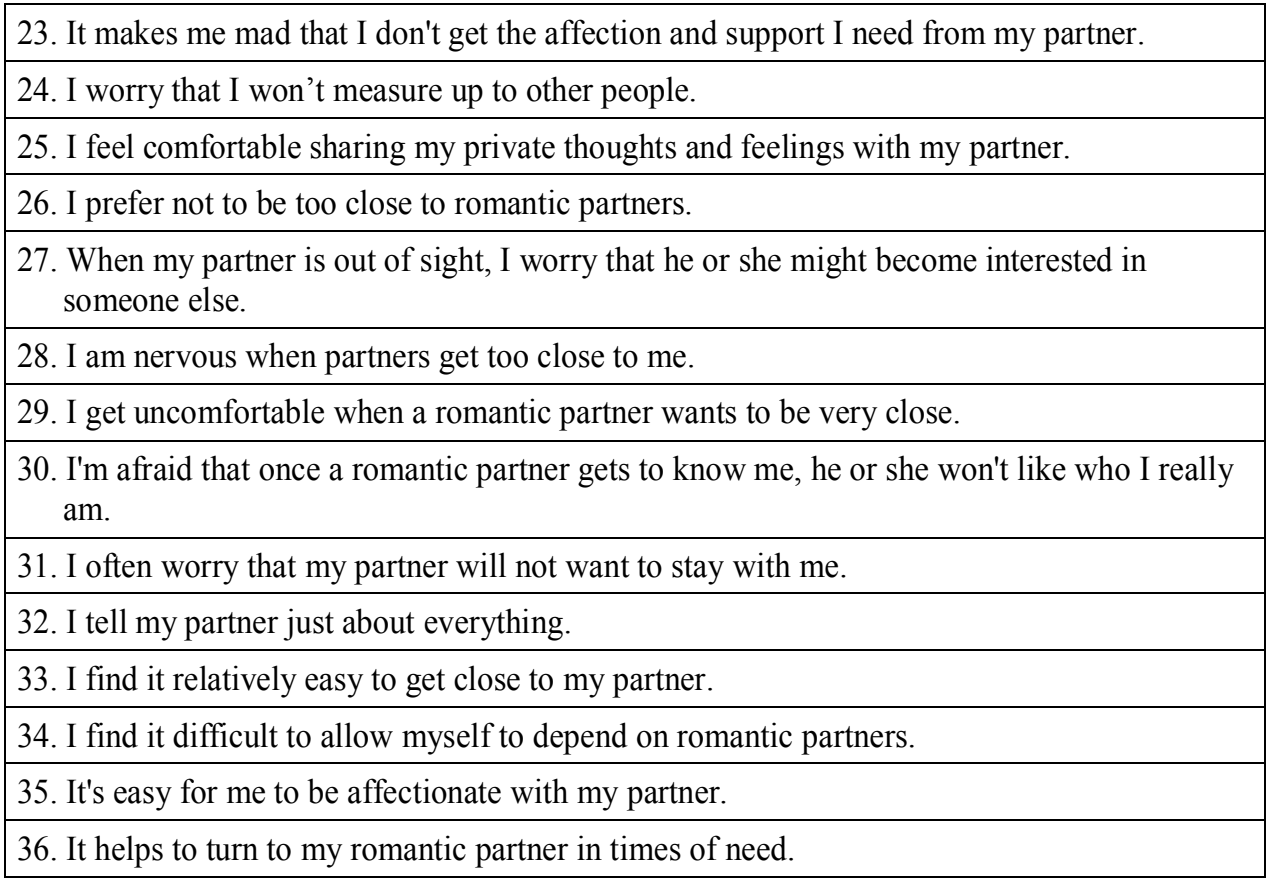

\section{DISCUSSION}

The results presented in Study 1 are similar to previous studies on the ECR-R. Cronbach's reliability was satisfactory. Exploratory analyses using the forced two-factor solution sorted the items of the Slovak version of ECR-R into relevant scales (Anxiety or Avoidance).

Wefound medium correlation between AnxietyandAvoidancesubscale $(\mathrm{r}=.365, \mathrm{p}<.001)$. Mild to medium strength of correlation between Anxiety and Avoidance scale has been found in numerous studies (see the results of recent meta-analysis in Cameron etal., 2012) and on the theoretical basis of a 2-factor adult attachment, such relationship is reasonable (Cassidy, Shaver, 2008).
Mean scores on both scales were similar to what Fraley (2012) reports. We found that men experience higher avoidance in close relationships, by contrast, women experience more anxiety in their close relationships. These results are in line with the results of meta-analysis of 100 studies $(\mathrm{N}>66000)$ on gender differences in adult romantic attachment (Del Giudice, 2011). This difference was statistically significant but of low effect size. The ECR-R is not a norm-based measure and differences in average scores can reflect true differences in experiencing adult attachment in men and women. For these reasons we would not recommend to correct the scores by re-weighing the scores according to gender.

We did not find any differences between the divorced and the married group. Several 
studies have found a relationship between quality of marital (or romantic) relationship and attachment styles. Secure attachment was found to be a predictor of marital satisfaction (although some studies proposed the opposite direction or more complex models), (see Cassidy, Shaver, 2008). Several perspectives and models have resulted in theories on the presence of a higher anxiety scale score in singles. An insightful review of usefulness of self-report measures of adult attachment in close-relationships was published by Feeney (2002). We find the results from Study 1 to be supportive of the claim of good validity of the Slovak version of the ECR-R.

A specific theoretical and statistical problem is the categorization of four attachment styles based on the ECR-R results. Different authors proposed different procedures for such groupings. Based on our analysis, $43 \%$ of the sample were categorized as having "Secure" attachment style, 18\% as having "Fearful", 22\% as having "Preoccupied" and $17 \%$ as having "Dismissive" attachment style. For a comparison, the prevalence rates in a large US national comorbidity survey that used an Adult attachment interview were as follows: $59 \%$, secure; $25.2 \%$, avoidant; $11.3 \%$, anxious; $4.5 \%$, unclassifiable (Mickelson et al., 1997). Shi (2003) also used a cluster analysis, but he clasified persons to clusters based on the raw scores. In comparison, when we used raw scores or factor scores from Oblique rotation in cluster analysis, the results were relatively different (differences between $5-10 \%$ in categories). We consider the factor scores from Varimax rotation as being the most suitable, because of the model proposed uncorrelated factors.

Study 2 focused on the concurrent and convergent validity of the ECR-R. We found a moderate correlation between the Anxiety scale and Neuroticism and a mild correlation of Avoidance and Neuroticism. As in numerous other studies, our results showed that the ECR-R cannot be fully reduced to or exchanged for the Big-Five personality trait model. In recent studies (Noftle, Shaver, 2006; Picardi et al., 2005), using the same assessment instrument employed in the present investigation and three different Big-Five measures, the Big-Five and Cloninger's temperament and character dimensions separately accounted for $20-41 \%$ of the variance in attachment-related anxiety and only $6-11 \%$ of the variance in attachment-related avoidance. Neuroticism (or Harm avoidance) can explain some variance in experiencing anxiety in adult romantic relationships, but the shared variance is not sufficient for the claim that feelings of insecurity are attributable only to the level of this personality trait, nor are attachment and personality constructs different names for the same thing ("jangle fallacy").

We explored the relationship between memories of parental rearing behavior and the ECR-R using the sEMBU. The results showed low levels of correlation and mixed results according to the theory, and we find these results to be not supportive for the convergent validity of the ECR-R. Altough we find the result to generally support the validity of the ECR-R and utility of the translated Slovak version of the ECR-R, in actual research there are several limitations to considering the ECR-R to be the ultimate measure of one's adult attachment experiencing. First of all, it is not clear how much of "attachment experiencing" the ECR-R (and related measures) reflects. Second, research analyzing subjective reports of adult attachment (like the ECR-R) and more indirect pro- 
cedures (like projective observer interviews based on Adult attachment intervies) showed only moderate correlation (Roisman et al., 2007). Third, the presented study focused only on the adult romantic relationships, although the ECR-R has been successfully used to measure experiencing attachment for other significant relationship figures like friends, coworkers and clients or patient-medical staff relations in health-care settings. And last, it is possible that the ECR$\mathrm{R}$ partially reflects the current mood of the respondent; a problem that exists with many questionnaire based methods, but is rarely considered.

The concept of Memories of parental rearing behavior was explored using the Slovak translation of the sEMBU. There is no Slovak or Czech standardization of the sEMBU available, but it is also worth noting, that our mean and SD values on all three sEMBU scales were very similar to the values in the original study by Perris (1980). We found only a couple mild to moderate correlations between the ECR-R and the sEMBU scales. These relationships seem reasonable and easy to interpret, but for the purpose of the study, we only concluded that both measures look at different yet related phenomena. Remembered parental behavior can be imprecise in numerous ways and its relationship to adult attachment perceived by the participant is only indirect and implicit.

\section{RESUME}

Although our results support the claim that the Slovak version of the ECR-R is a valid and reliable measure of self-reported adult attachment, further research is needed. We recommend looking into the relationship between Slovak ECR-R and other measures of adult attachment. Particularly useful would be to analyze the relationship between selfreport and interview, based on behavioral analysis of adult attachment. Further research on at least the short-term temporal stability of the Slovak version of the ECR-R is advisable, in order to gain further information on the reliability of the measure (Sibley, Liu, 2007). The full 36-item version of the ECR-R can be too time-consuming for certain complex research settings where there are other measured variables, so a shorter version of fewer carefully chosen items from the full ECR-R version could be useful as well. For the use of the Slovak version of the ECR-R, our study was aimed at older adults and their experiences with romantic attachment for a more general application of the translated version (for review on age and attachment see Browne, Shlosberg, 2006).

Received February 23, 2013

\section{REFERENCES}

AINSWORTH, M., BLEHAR, M., WATERS, E., WALL, S., 1978, Patterns of attachment: A psychological study of the strange situation. Hillsdale, NJ: Erlbaum.

ALONSO-ARBIOL, I., BALLUERKA, N., SHAVER, P.R., 2007, A Spanish version of the Experiences in Close Relationships (ECR) adult attachment questionnaire. Personal Relationships, 14, 1, 45-63.

ATKINSON, L., GOLDBERG, S. (Eds). (2004). Attachment issues in psychopathology and intervention. London: Lawrence Erlbaum.

ARRINDEL, W.A., SANAVIO, E., AGUILAR, G., SICA, C., HATZICHRISTOU, CH., EISEMANN, M., RECINOS, L.A., GASZNER, P., PETER, M., BATTAGLIESE, G., KALLAI, J., VAN DER ENDE, J., 1999, The development of a short form of the EMBU: Its aprrraisal with students in Greece, Guatemala, Hungary and Italy. Personality and individual Differences, 27, 4, 613-628.

BIEŠČAD, M., HAŠTO, J., 2010, Diagnostikovanie typov vzt'ahovej väzby (attachment) v 
dospelosti s použitím nástrojov dostupných v našich podmienkach [Diagnosing of attachment types in adulthood using available tools]. Psychiatrie, 14, 2, 68-74.

BOWLBY, J., 1969, Attachment and loss: vol. 1. Attachment. New York: Basic Books.

BROWNE, C.J., SHLOSBERG, E., 2006, Attachment theory, ageing and dementia: A review of the literature. Aging \& Mental Health, 10, 2, 134-142.

CAMERON, J.J., FINNEGAN, H., MORRY, M.M., 2012, Orthogonal dreams in an oblique world A meta-analysis of the association between attachment anxiety and avoidance. Journal of Research in Personality, 46, 5, 472-476.

CASSIDY, J., SHAVER, P.R., 2008, Handbook of attachment: Theory, research, and clinical applications (2nd ed.). New York: The Guilford Press.

CLONINGER, R.C., SVRAKIC, D.M., 1997, Integrative psychobiological approach to psychiatric assessment and treatment. Psychiatry: Interpersonal \& Biological Processes, 60, 2, 120-144.

COSTA, P.T., Jr., McCRAE, R.R., 1995, Domains and facets: Hierarchical personality assessment using the Revised NEO Personality Inventory. Journal of Personality Assessment, 64, 1, 21-50.

CHOTAI, J., JONASSON, M., HÄGGLÖF, B., ADOLFSSON, R., 2005, Adolescent attachment styles and their relation to the temperament and character traits of personality in a general population. European Psychiatry, 20, 3, 251-259.

FRALEY, R.C., 2012, Information on the Experiences in Close Relationships-Revised (ECR-R) Adult Attachment Questionnaire. Published on: http://internal.psychology.illinois.edu/ rcfraley/ measures/ecrr.htm (2012/12/19).

FRALEY, R.C., SHAVER, P.R., 2000, Adult romantic attachment: Theoretical developments, emerging controversies, and unanswered questions. Review of General Psychology, 4, 2, 132 154.

FRALEY, R.C., WALLER, N.G., BRENNAN, K.A., 2000, An item-response theory analysis of self-report measures of adult attachment. Journal of Personality and Social Psychology, 78, 2, 350365.

GIUDICE, D.M., 2011, Sex differences in romantic attachment: A meta-analysis. Personality and Social Psychology Bulletin, 37, 2, 193-214.

GÜNGÖR, D., BORNSTEIN, M.H., 2010, Culture-general and -specific associations of attach- ment avoidance and anxiety with perceived parental warmth and psychological control among Turk and Belgian adolescents. Journal of Adolescence, 33, 5, 593-602.

LEČBYCH, M., POSPÍŠILÍKOVÁ, K., 2012 , Česká verze škály Experiences in Close Relationships (ECR): Pilotní studie posouzení vztahové vazby v dospělosti. [Czech version of the scale Experiences in Close Relationships (ECR): Pilot study of attachment in adulthood]. E-psychologie, 6, 3, $1-11$.

MAK, M., BOND, M., SIMPSON, J.A., RHOLES, W., 2010, Adult attachment, perceived support, and depressive symptoms in Chinese and American cultures. Journal of Social \& Clinical Psychology, 29, 2, 144-165.

LIVIANOS-ALDANA, L., ROJO-MORENO, L., 2003 , Construct validity of retrospective perception of parental relating scales: EMBU and PBI. Personality and Individual Differences, 35, 7, 17071718.

MERCER, J., 2006, Understanding attachment. Westport, CT: Praeger.

MICKELSON, K.D., KESSLER, R.C., SHAVER, P.R., 1997, Adult attachment in a nationally representative sample. Journal of Personality and Social Psychology, 73, 5, 1092-1106.

MIKULINCER, M., SHAVER, P.R., 2007, Attachment in adulthood. Structure, dynamics, and change. New York: The Guilford Press.

NOFTlE, E.E., PHILliP, R., SHAVER, P.R., 2006, Attachment dimensions and the big-five personality traits: Associations and comparative ability to predict relationship quality. Journal of Research in Personality, 40, 1, 179-208.

OBEGI, J.H., BERANT, E. (Eds.), 2009, Attachment theory and research in clinical work with adults. New York: The Guilford Press.

OLSSØN, I., SØREBØ, Ø., DAHL, A., 2010, The Norwegian version of the Experiences in Close Relationships measure of adult attachment: Psychometric properties and normative data. Nordic Journal of Psychiatry, 64, 5, 340349.

PARKER, M.L., JOHNSON, L., KETRING, S.A., 2011, Assessing attachment of couples in therapy: A factor analysis of the experiences in Close Relationships Scale. Contemporary Family Therapy, 33, 1, 37-48.

POLIAKOVÁ, M., MOJŽIŠOVÁ, V., HAŠTO, J., 2007, Skrátený dotazník zapamätaného rodičovského správania ako výskumný klinický nástroj s.E.M.B.U. [Abbreviated questionnaire of 
remembered parent behavior as a clinical research tool sEMBU]. Psychiatria-PsychoterapiaPsychosomatika, 14, 2-3, 79-88.

PERRIS, C., JACOBSON, L., LINDSTRÖM, H., VON KNORRING, L., PERRIS, H., 1980, Development of a new inventory for assessing memories of parental rearing behaviour. Acta psychiatrica Scandinavica, 61, 4, 265-274.

PICARDI, A., CAROPPO, E., TONI, A., BITETTI, D., DI MARIA, G., 2005, Stability of attachment-related anxiety and avoidance and their relationships with the ve-factor model and the psychobiological model of personality. Psychology and Psychotherapy: Theory, Research and Practice, 78 , 3, 327-345.

RAVITZ, P., MAUNDER, R., HUNTER, J., STHANKIYA, B., LANCEE, W., 2010, Adult attachment measures: A 25 -year review. Journal of Psychosomatic Research, 69, 419-432.

ROISMAN, G.I., HOLLAND, A., FORTUNA, K., FRALEY, R.C., CLAUSELl, E., CLARKE, A. 2007, The adult attachment interview and self-re- ports of attachment style: An empirical rapprochement. Journal of Personality and Social Psychology, 92, 4, 678-697.

RUISEL, I., HALAMA, P., 2007, NEO-FFI. NEO pätfaktorový osobnostný inventár. [NEO Five Factor Inventory]. Praha: Hofrege, Testcentrum.

SHI, L., 2003, The association between adult attachment styles and conflict resolution in romantic relationships. American Journal of Family Therapy, 31, 3, 143-157.

SIBLEY, C.G., LIU, J.H., 2004, Short-term temporal stability and factor structure of the Revised Experiences in Close Relationships (ECR-R) measure of adult attachment. Personality and Individual Differences, 36, 4, 969-975.

SURCINELLI, P., ROSSI, N., MONTEBAROCCI, O., BALDARO, B., 2010, Adult attachment styles and psychological disease: Examining the mediating role of personality traits. The Journal of Psychology, 144, 6, 523-534.

WAKE, L., 2010, Role of brief therapy in attachment disorders. London: Karnak Books.

\title{
PSYCHOMETRICKÉVLASTNOSTISLOVENSKEJ VERZIE DOTAZNÍKA „AKO PREŽIIVAM BLÍZKEE VZŤAHY“(EXPERIENCES IN CLOSE RELATION- SHIPS-REVISITED, ECR-R) V DOSPELEJPOPULAČNEJVZORKE
}

\author{
G. R o z v a d s ký Gu gová, A. H e r e t i k, M. H a j d ú k
}

Súhrn: Experiences in close relationship-revisited (ECR-R) je najpoužívanejšou sebaposudzovacou metódou pre vzt'ahovú väzbu v dospelosti. Mnohé štúdie ukázali všeobecnú užitočnost' tohto dotazníka v rôznom jazykovom a kultúrnom prostredí. Niektoré štúdie však poukázali na významné kultúrne a národnostné (jazykové) rozdiely v štruktúre štýlu vzt’ahovej väzby, ako aj potrebu prispôsobit’ či preformulovat' niektoré položky metódy. V štúdii sme skúmali psychometrické vlastnosti slovenského prekladu ECR-R (slovensky: „Ako prežívam blízke vztahy“) na vzorke z dospelej populácie (Štúdia 1, n=921). V Štúdii $2(\mathrm{n}=100)$ vyplnili účastníci výskumu aj slovenskú verziu NEO-FFI s ciel'om získat' d’alšie informácie o vzt’ahu ECR-R $\mathrm{k}$ dominujúcemu pätfaktorovému modelu osobnosti a slovenský preklad sEMBU (slovensky „Moje spomienky na to, ako ma vychovávali“) z hladiska konvergentnej validity metódy. Výsledky analýz poukazujú na dobré psychometrické vlastnosti slovenského prekladu ECR-R. Exploračná faktorová analýza zoradila položky do škál presne tak, ako to autori ECR-R predpokladali. Našli sme mierne až stredne silné korelácie medzi škálou Úzkost' a Vyhýbanie (ECR-R) a Neurotizmom (NEO-FFI) a mierne korelácie s niektorými škálami sEMBU. V diskusii a závere uvádzame d’alšie návrhy výskumných štúdí, ktoré by pomohli k lepším znalostiam a využitiu slovenskej verzie ECR-R. 